\title{
Sensory evaluation of ice cream with hydrosoluble soy extract
}

\author{
Bueno, M.M., *Antunes, V.C. and Castro, W.F. \\ Federal Institute of Sao Paulo/IFSP Campus Barretos Avenue C-1, number 250. Barretos/SP. Brazil. \\ Postal code: $14781-502$
}

\begin{abstract}
Article history:
Received: 17 October 2017

Received in revised form: 15

November 2017

Accepted: 19 November 2017

Available Online: 23

November 2017
\end{abstract}

\section{Keywords:}

Ice cream,

Soy,

Sensory acceptance

DOI:

https://doi.org/10.26656/fr.2017.2(2).260

\begin{abstract}
Ice cream is a nutritious food because it contains ingredients responsible for supplying energy to the body. Soy has a high nutritional value and functional properties which make it to be an alternative ingredient to replace cow's milk. The purpose of this paper was to formulate an ice cream with hydrosoluble soy extract and submitted to a sensory evaluation. Two formulations of ice cream were prepared: one soy-based and the other with cow's milk (control). Both ice creams were submitted to a sensory evaluation in order to evaluate the appearance, flavor and texture attributes, for this examination it was used the hedonic scale of nine points. For the appearance attribute, the soy-based ice cream had an average score of 7.6, which means between "liked moderately and liked very much", and cow's milk ice cream had an average score of 8.1, "liked very much". For the texture attribute, the soy-based ice cream reached an average of 7.4, meaning "like moderately" and "liked very much" and the cow's milk ice cream obtained an average of 8.2, meaning "liked very much". The flavor attribute had an average score of 6.1, meaning "liked slightly" and 8.2 "liked very much" for the soy-based ice cream and the cow's milk ice cream respectively. When the assessors were asked about their purchase intention, $68 \%$ said that certainly they would buy the control sample and $32 \%$ definitely or probably would buy the soy-based ice cream. The sensory parameters evaluated showed that the soy -based ice cream had a good acceptance.
\end{abstract}

\section{Introduction}

Brazil is the second largest soy producer being surpassed only by the United States. In the 2016/2017 harvest it was produced 351 million tonnes in the world, and through this among 113 tonnes were produced in Brazil (Embrapa Soja, 2017). However, only from the end of the 1990s, the Brazilian industry began to adopt new technologies for obtaining soy extract with better sensorial quality, leading the release of a greater variety of soy products on the market (Behrens and Silva, 2004), for example, soy milk, with and without the addition of fruit juice, yogurt, soy soup among others. Despite technological advances, the challenge of improving the residual soy taste has not yet been reached (Chamba et al., 2014).

In the past, the soy nutritional importance of was correlated only with the protein content, and because of this, it is called "vegetal meat", but currently its functional properties have been widely studied and incorporated into the healthy eating habits.

The nutritional value of soy becomes evident, as it has in its composition considerable quantities of minerals such as potassium, phosphorus, and vitamins.There are also other components that stand out with functional properties, with evidence for the isoflavones, which have antioxidant activity by reducing the risk of several types of cancer (breast, prostate, and colon), cardiovascular diseases, bone loss after menopause and osteoporosis (Esteves and Monteiro, 2001; Goes-Favoni et al., 2004).

According to the National Health Surveillance Agency of Brazil (ANVISA), ice cream and edible ice are food products obtained from an emulsion of fats and proteins, with or without the addition of other ingredients and substances, or even from a mixture of water, sugar and other ingredients or substances that had been subjected to freezing, under conditions that ensure the preservation of the frozen or partially frozen product during storage, period transportation and delivery to consumption (Brasil, 2003).

According to data from the Brazilian Association of Industries and Ice Cream Industry, ABIS (2017), during the summertime in Brazil, it is consumed approximately 
$70 \%$ of the annual production of ice cream. In 2016, it was produced 1.002 million liters of ice cream, from which it as possible register a growth of $68.4 \%$ in the production comparing to 2003.

The ice cream can be considered a nutritious food because it contains ingredients from the macronutrients, such as carbohydrates, proteins, and lipids, which are responsible for supplying energy that ensures a healthy diet (Marshall and Arbuckle, 1996). Ice cream is also appreciated by the different age groups (Munhoz et al., 2010).

The ice cream of soy become a good alternative for those lactose-intolerant, who are unable to digest the sugar existent in milk. Lactase, the intestinal enzyme, responsible for the hydrolysis of lactose into simpler sugars: glucose and galactose.The most common symptoms of this disease are nausea, flatulence, abdominal pain and diarrhea (Quilici and Missio, 2014). In addition, the consumption of ice cream of soy is a way to stimulate the consumption of soy getting their benefits (Halim et al., 2014).

The purpose of this study was to develop and verify the sensory acceptance of an ice cream-based on hydrosoluble soy extract with strawberry flavor.

\section{Material and methods}

\subsection{Preparation of hydrosoluble soy extract}

The hydrosoluble soy extract was obtained in accordance with the methodology of Zadinello et al. (2010). Once selected, 300g of whole grain of soy (Yoki Foods S.A.) was weighed, placed in a refractory container $(500 \mathrm{~mL})$ and it was heated in a microwave oven (Maxxi, Brastemp, Whirlpool Corporation/ Michigan/USA capacity of $50 \mathrm{~L}$ ) for 3 minutes and 20 seconds, in maximum power.Subsequently, these soybeans were placed in a refractory container with 900 $\mathrm{mL}$ of water and brought to fire in a double boiler for 30 minutes.After the cooking process was finished the water was thrown away, the material was homogenized in a blender (Model LAR 25, Metallurgical Siemsen, Brusque/SC, Brazil with a capacity of $20 \mathrm{~L}$ ) for 5 minutes, at maximum power with $2100 \mathrm{~mL}$ of water and it was filtered in a coffee filters of paper are made from about $100 \mathrm{~g} / \mathrm{m}^{2}$. Then, $140 \mathrm{~g}$ of sucrose and $1.6 \mathrm{~g} \mathrm{NaCl}$ were added and mixed a blender for 3 minutes at maximum power. As a result, it was obtained approximately $2100 \mathrm{~mL}$ of hydrosoluble soy extract.

\subsection{Preparation of ice cream}

Both ice creams were produced the traditional one and the soy-based ice cream, in which the cow's milk was replaced by the hydrosoluble soy extract according to the formulation described in Table 1. The ice creams were prepared on a pilot scale, according to the flowchart in Figure 1.

Table 1. The formulations of the cow's milk ice cream and of the soy-based ice cream

\begin{tabular}{lcc}
\hline \multicolumn{1}{c}{ Components } & $\begin{array}{c}\text { Cow's Milk Ice } \\
\text { Cream (\%) }\end{array}$ & $\begin{array}{c}\text { Ice Cream Soy- } \\
\text { Based (\%) }\end{array}$ \\
\hline Hydrosoluble soy & - & 81 \\
extract & 81 & - \\
Milk & 16 & 16 \\
Sucrose & 1.6 & 1.6 \\
Strawberry flavour & 0.8 & 0.8 \\
Emulsifier & 0.25 & 0.25 \\
Guar gum based product & (thickening agent) & \\
\hline
\end{tabular}

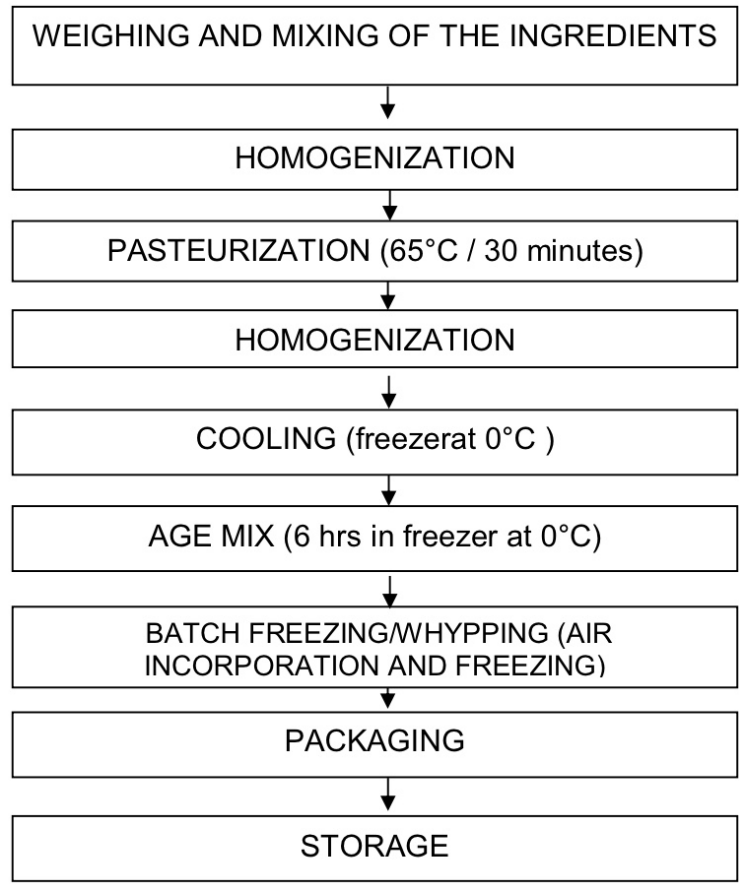

Figure 1. Flowchart of the flavored strawberry cow's milk ice cream and the soy-based ice cream

\subsection{Overrun}

The overrun's calculation was performed according to the equation below (Halim, 2014).

$$
\text { Overrun }=\frac{\text { Mix's weight }- \text { Ice cream'sweight }}{\text { Ice cream's weight }} \times 100
$$

\subsection{Sensory evaluation}

In order to verify the acceptance and the purchase intention, the test was performed at the Federal Institute of São Paulo (Câmpus Barretos), with the intention to sensorially evaluate both formulations. The test was made by 101 assessors not trained, within a wide range of age and from both sexes.

The assessors must score these three attributes: appearance, flavor, and texture. For this purpose, they used a structured 9 points hedonic scale, using ranges varying from "dislike very extremely" to "liked 
extremely" (Villanueva and Da Silva, 2009).

The samples were presented in a monadway (individually) in cups made of polystyrene $(50 \mathrm{~mL})$ at a temperature in the range of -10 to $0^{\circ} \mathrm{C}$.The assessors were also asked about their habit of soy consumption. The data were analyzed by ANOVA and averages were compared by Tukey Test at 5\% level of probability, using Assistat.

This study was submitted to the Brazilian Platform for evaluation of the Ethics Committee-CEP/IFSP, and it was approved, with CAAE (Certificate of Appreciation for Ethics Committee) 38867014.6.0000.5473.

\section{Results and discussion}

Most of the assessor was female and presented the age range of 15 to 60 years. However, $66 \%$ were less than 30 years old, which lead us to state that they are not possibly consumers of the soy ice cream yet, once they are still slightly concerned about the consumption of soy products and also they are not worried about the advantage of their functional properties. This fact was confirmed by the low percentage $(19 \%)$ of assessors who have the habit of consuming soy products, they have stated that they consume this kind of products only once a month $(42 \%)$, as shown in Figure 2.

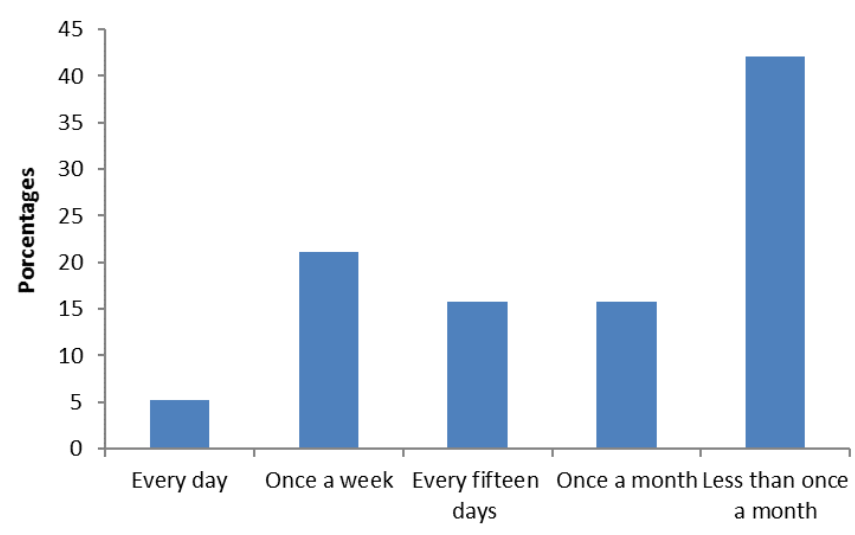

Figure 2. Frequency of soy products consumption.

It was noted that the soy products that are the most consumed by the by participants are the "hydrosoluble soy extract" (37\%) and soy milk with fruit juice (37\%), as indicated in the literature that shows the increase in consumption of soy-based drinks (Silva et al., 2007).

The present research showed data which are similar to the work of Junior et al. (2010), where $31 \%$ of the men and $37 \%$ of the women participating stated that they consume soy milk, with a frequency of 5 times a month maximum, in a total of $35 \%$ of the interviewed (men and women).

In sensory evaluation, the soy-based ice cream had a good acceptance in sensory (Table 2), although significant difference $(\mathrm{p}<0.05)$ in relation to the cow's milk ice cream (traditional).

With regard to appearance, the ice cream soy-based obtained average rating equal to 7.6 remaining between the terms "liked moderately" and "I liked it a lot", while the ice cream with cow's milk reached average grade 8.1 indicating that consumers "really liked" the appearance. This significant difference maybe the result of the pinkyellowish tone presented in ice cream soy-based (Figure $3)$.

Table 2. Average notes for the sensory attributes assessed by acceptance test with 101 assessors to the ice cream's formulations.

\begin{tabular}{lccc}
\hline & Appearance & Taste & Texture \\
\hline $\begin{array}{l}\text { Cow's Milk ice } \\
\text { cream }\end{array}$ & $8.12 \pm 0.88^{\mathrm{a}}$ & $8.23 \pm 0.86^{\mathrm{a}}$ & $8.23 \pm 0.89^{\mathrm{a}}$ \\
$\begin{array}{l}\text { Soy-based ice } \\
\text { cream }\end{array}$ & $7.58 \pm 1.38^{\mathrm{b}}$ & $6.08 \pm 2.12^{\mathrm{b}}$ & $7.42 \pm 1.34^{\mathrm{b}}$ \\
\hline
\end{tabular}

Mean \pm standard deviation. For the same column, means with different alphabet superscript indicates significant difference by Tukey test $(\mathrm{p}<0.05)$.

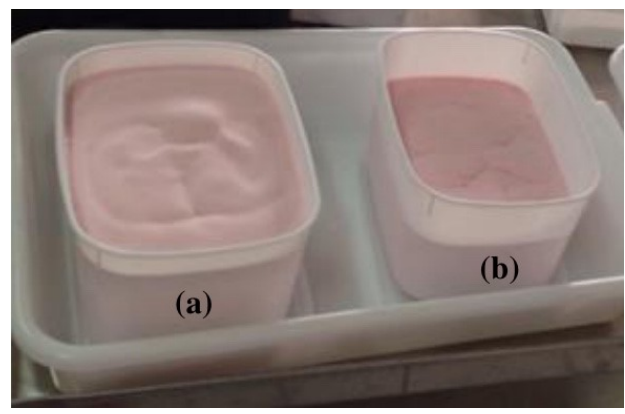

Figure 3. Soy-based ice cream (a) and cow's milk ice cream (b)

For the attribute "taste", as it was expected, the ice cream formulated with soy had the lowest average (6.1) which corresponds to the acceptance "I enjoyed slightly", on the other hand, the traditional ice cream reached average (8.2) which is equivalent to the term "liked it very much". Despite this, it can be stated that the result obtained from the soy-based ice cream is considered satisfactory since $80 \%$ of the participants assumed that they are not used to consuming soy products. Cardoso et al. (2011) also reported low acceptance for the attribute taste, which is perfectly justifiable, since soy products have slightly unpleasant flavor to the Brazilian taste because they don't have the habit of eating it.

For the attribute texture, the soy-based ice cream, obtained an average 7.4, getting between the terms "I enjoyed moderately" and "liked it very much" whereas the traditional ice cream presented rate 8.2, showing average rating higher than the soy-based ice cream. This significant difference between the soy-based ice cream and the traditional one might have occurred because on the formulation of cow`s milk ice cream there are components (fat and protein) that would have influenced 
the texture of the final product. This fact is emphasized by the overrun of the soy-based ice cream sample obtained the value of $11.65 \%$ against $15.3 \%$ of the traditional.

For the test of purchase intention, there was also a significant difference $(p<0.05)$ between the samples. With regards to assessors, $68 \%$ mentioned that "certainly would buy the cow's milk ice cream ", whereas $32 \%$ answered that "definitely or probably would buy the soybased ice cream". It is important to state that even if this result seems to be low, it can be a good result once it is related to a product made by soy.

The results obtained suggested that these consumers only would buy the soy-based ice cream if they have a restriction to milk components.

\section{Conclusion}

The soy-based ice cream had a good acceptance based on the sensory parameters evaluated, demonstrating the great potential of acceptation in the market for people intolerant to lactose or who want to consume food health claim purpose. However, to ensure that the soy-based ice cream reaches higher rates for consumers, in general, it will be necessary to find methods for the soy processing that make it more attractive to the palate.

\section{Acknowledgments}

Special thanks to Prof. Dsc. Marcela O. Pagoto de Souza for reviewing the article.

\section{References}

Associação Brasileira das Indústrias e do Setor de sorvete (ABIS). (2017). Retrieved on September 24, 2017 from ABIS Website: http://www.abis.com.br.

Behrens, J.H. and Silva, M.A.A.P. (2004). Consumer attitude towards soybean and related products. Food Science and Technology, 24, 431-439. https:// doi.org/10.1590/S0101-20612004000300023

Brasil. (2003). Ministério da Saúde. Agência de vigilância Sanitária. Resolução RDC no 267, de 22 de setembro de 2003. Regulamento Técnico de Boas Práticas de Fabricação para Estabelecimentos Industrializadores de Gelados Comestíveis. Diário Oficial da República Federativa do Brasil, Poder Executivo, Brasília, 26 de setembro de 2003. Retrieved on September 15, 2017 from Website: // http://portal.anvisa.gov.br/wps/wcm/ connect/9f880600474595599d2edd3fbc4c6735/ RDC_267_2003.pdf?MOD=AJPERES

Cardoso J.R., Pessoa R.A. and Ramos L.S.N. (2011). Elaboração de sorvete de abacate à base de leite de vaca e extrato hidrossolúvel de soja. Revista ACTA Tecnológica - Revista Científica, 6(2), 7-11.

Chamba, M.V.M., Hua, Y. and Simwaka, J.E. (2014). Comparative sensory evaluation of soy protein isolates extracted from full fat and defatted flours using natural and conventional synthetic extraction chemicals. International Food Research Journal, 21 (1), 209-215.

Embrapa Soja - Empresa Brasileira de Pesquisa Agropecuária. (2017). Soja em números. Retrieved on April 24, 2017 from EMBRAPA Website: https:// www.embrapa.br/soja/cultivos/soja1/dadoseconomicos.

Esteves E.A. and Monteiro J.B.R. (2001). Beneficial effects of soy isoflavones on chronic diseases. Brazilian Journal of Nutrition, 14(1), 43-53.

Goes-Favoni, S.P., Beleia, A.D.P., Carrao-Panizzi, M.C. and Mandarino J.M.G. (2004). Isoflavones in commercial soy foods. Food Science and Technology, 24(4), 582-586.

Halim N.R.A., Shukri W.H.Z., Lani M.N. and Sarbon N.M. (2014). Effect of different hydrocolloids on the physicochemical properties, microbiological quality and sensory acceptance of fermented cassava (tapaiubi) ice cream. International Food Research Journal, 21(5), 1825-1836.

Marshall, R.T. and Arbuckle, W.S. (1996). Ice cream. $5^{\text {th }}$ ed, p. 349. New York: International Thomson Publ. https://doi.org/10.1007/978-1-4613-0477-7

Munhoz C.L., Silva T.V., Teleginski F., Poposki M. and Sanjinez-Argandona E.J. (2010). Development of soybean ice cream and crunchy coverage from okara. Ambiência, 6(3), 493-500.

Quilici F.A. and Missio, A. (2014). Retrieved on April 24, 2017 from Website http:// www.unigastrocampinas.com.br/artigos/ intolerancia.pdf.

Silva J.B., Prudêncio S.H., Felberg I., Deliza R. and Carrao-Panizzi M.C. (2007). Acceptability of drinks prepared with different water-soluble soy extracts. Pesquisa Agropecuária Brasileira, 42(12), 1779$1784 . \quad$ https://doi.org/10.1590/S0100204X2007001200016

Villanueva, N.D.M. and Da Silva, M.A.A.P. (2009). Comparative performance of the nine-point hedonic, hybrid and self-adjusting scales in the generation of internal preference maps. Food Quality and Preference, 20, 1-12. https://doi.org/10.1016/ j.foodqual.2008.06.003

Zadinello R.E., Coelho S.R.M., Téo C.R.P.A. and Nóbrega L.H.P. (2010). Métodos de extração, formulação e avaliação sensorial de produto à base de extrato hidrossolúvel de soja. Revista Varia Scientia Agrárias, 1(1), 111-120. 